\title{
Biosphere reserves as a long-term intervention in a region - strategies, processes, topics and principles of different participative planning and management regimes of biosphere reserves
}

\author{
Michael Jungmeier, Ina Paul-Horn, Daniel Zollner, Falk Borsdorf, Karin Grasenick, Sigrun Lange \& Birgit Reutz- \\ Hornsteiner
}

Keywords: biosphere reserve, protected area management, planning, intervention, participation, governance, change management

\section{Abstract}

The management of protected areas has recently emerged as a new scientific discipline. To date, there is a lack of systematic and theoretical background. This study explored this vast field by combining different disciplines in an inter- and transdisciplinary approach. Taking two existing Austrian biosphere reserves (Großes Walsertal BR, Wienerwald BR) and one national park (Nockberge NP, BR planned) as typical examples, we analysed basic management principles in terms of intervention, participation, regional governance and change management. The broad base and special methodological approach showed the complexity of planning and managing a biosphere reserve. How local stakeholders perceive the process of development very often differs from what the planning regime was meant to do. The overwhelming importance of regional history, the power of established structures and social components (trust, enthusiasm etc.) can turn planning intentions into an unpredictable direction. Only a precise and focused strategic mix of process components can ensure a successful process. What constitutes an effective mix differs from region to region and must be defined individually. It also became clear that different phases of BR development need specific management approaches as intervention takes place in a typical order. Once again, proper participation proved crucial for the success of a BR.
Profile

Protected Area

Großes Walsertal BR

Wienerwald BR

Nockberge NP

Mountain range

Alps

Country

Austria

\section{Introduction}

Planning protected areas in general and biosphere reserves (BR) in particular is one of the largest spatial planning processes in modern society. Managing a BR may be seen as a continuous process of regional intervention, participation and governance as well as a form of change management. There are some studies dealing with the disciplines involved in the context of protected areas (Graham et al. 2003; Jungmeier \& Zollner 2004; Borrini-Feyerabend 2004; Erdmann et al. 2004; Coy \& Weixlbaumer 2006; Fürst et al. 2006; Hussong 2006; Meyer \& Klingele 2007; StollKleemann \& Welp 2008; Getzner \& Jungmeier 2009; Lahner 2009; Getzner et al. 2010), but there is a lack of systematic and holistic reflection and theory, as reflected in the fact that the management of protected areas is considered a new scientific discipline (Getzner \& Jungmeier 2009).

The Austrian Academy of Sciences supported an interdisciplinary research team to analyse the interrelation between the protected area and the region in the case of three Austrian BRs. The project Participation processes in biosphere reserves - intervention theory, analysis of strategies and procedural ethics in the case of Wienerwald BR, Großes Walsertal BR und Nockberge NP addressed several research questions. Here we will pick up on two themes:

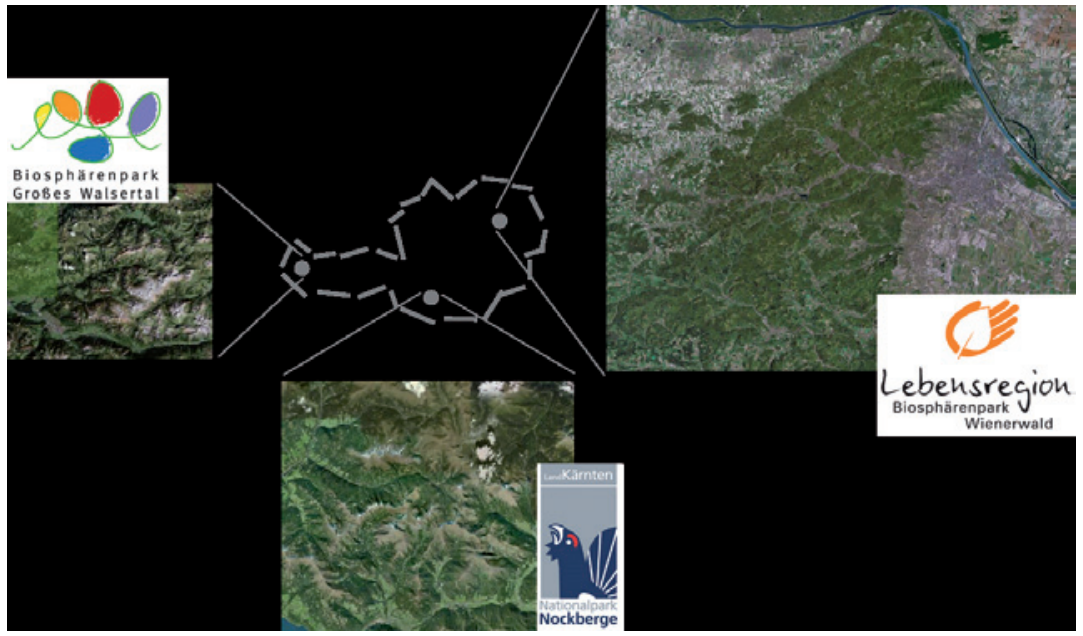

Figure 1 - Location of the case studies.

What was the initial perception of local stakeholders of the planning and management of the BR? Which were the main topics, strategies and participative approaches in the course of the development?

\section{Diversity of perspectives and methods}

Complexity-oriented research questions / (knowledge) disciplines with a large spatial scale require methodological pluralism (Kastenhofer 2009). This approach is 


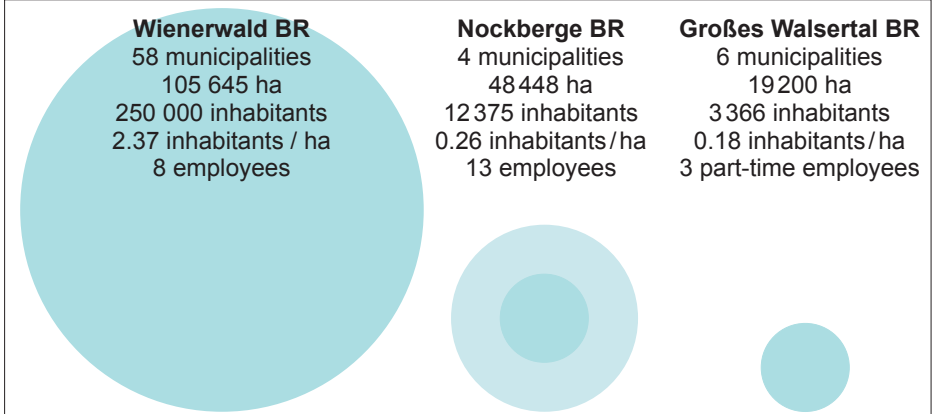

Figure 2 - Comparison of the three test sites.

Key figures indicate the great differences in size and population of the three test sites. This diversity was welcome as an incentive to broaden the approaches and the results. Wienerwald BR is run by a non-profit organization founded by the federal states of Lower Austria and Vienna; Nockberge NP is underpublic administration and Großes Walsertal BR is run by an NGO.

necessary to tease out the whole potential spectrum. The findings summed up in this article should be seen as integrative results from converging perspectives and methods.

The research team of this project worked closely together with planners, advisers and managers of the sites. Below we have listed the issues and perspectives (disciplines):

Intervention theory and intervention ethics: systematic intervention research, as defined by Krainz \& Paul-Horn (2009) as well as Heintel (2003), is focusing on societal learning processes. For our purposes, we widened the term intervention by including its original meaning of coming between (lat. inter venire). Intervention is also an artificial, governmental or planning impact into a system, carried out by diverse strategies and instruments.

Participation: the project refers to the four approaches described by Stoll-Kleeman \& Welp (2008): routine management, sector-based participatory management, social and environmental engineering, management as mutual learning.

Regional governance: sustainable regional development processes and policies depend upon the interaction of stakeholders from all sectors of society. These relations between local and regional government institutions as well as locally and regionally active enterprises and civil society organizations, are often coordinated by an institution that sits right at the critical juncture within the regional networks (Fürst 2006; Fürst et al. 2006). BR administrations take on this task in the case of BRs (Lahner 2009).

Diversity management: for Finke (2006), diversity management aims to leverage the diversity in an organization or in a particular environment. In the context of a biosphere region, the involvement of different groups of stakeholders and their capabilities is of particular relevance.

Primarily, change management deals with institutional or organizational changes (Inversini 2008). We applied the principles of transformation phases as defined by Bridges (2003) and a formula revising the prerequi- sites of successful change processes (Dannemiller Tyson Ass. 2000) to change processes in a region in general and a BR in particular. Bearing in mind these research questions and perspectives, we used the following methods (and adapted some of them to the relevant disciplines):

- memory mapping, a method particularly suited to visualizing regional processes in a participatory way (according to Getzner et al. 2008) - used in different settings in all three BRs;

participatory observation during selected events (after Paul-Horn 2006) - used in Nockberge NP and Wienerwald BR;

standardized questionnaires to assess the status of the sites (adapted from Jungmeier et al. 2005; Flick et al. 2009) - used in all sites;

qualitative interviews for in-depth information on the stakeholders' perceptions (after Flick et al. 2009; Girtler 1992) - used in Nockberge NP;

Delphi survey (according to Häder 2008) - used in Wienerwald BR;

regional feedback loops as used in intervention research (Heintel 2003) - used in Großes Walsertal BR and in Nockberge NP;

expert workshops (open discussions of all perspectives, hypothesis testing through all disciplines).

\section{Regional context: case studies in three Aus- trian BRs}

The study is based on an empirical assessment of planning and management processes in three Austrian BRs, one of them currently in the early stages of establishment.

Großes Walsertal BR in the federal state of Vorarlberg covers an area of $192 \mathrm{~km}^{2}$. It is an economically less favoured region and considered culturally homogenous. The BR was established in a participative process and internationally recognized in the year 2000. Planning and management has been, and still is, approaching and involving stakeholders personally, which is relatively easy in a region with some 3400 inhabitants spread over six municipalities (Coy \& Weixlbaumer 2006; Zollner et al. 2006; Reutz-Hornsteiner 2003, 2002, 2001).

Wienerwald BR spreads across two federal states, Lower Austria and Vienna, and covers an area of $1056 \mathrm{~km}^{2}$. It includes 58 municipalities with a total of more than 200000 inhabitants. In economic terms, the site ranges from rural settlements to (peri-)urban areas. Geographically the local communities are oriented in different directions. This makes broad participation processes difficult and complex. Therefore the BR management orients its communication on specific target groups (Köck et al. 2009; Jungmeier \& Kirchmeir 2008; Lackner \& Loiskandl 2007; Zollner et al. 2006; Kirchmeir et al. 2005; Arge Wienerwald 2002).

Nockberge BR (planned): Nockberge NP was established by Carinthian law in 1987. Since one of the key 
factors, the cultural landscape (mainly alpine pastures), does not fulfil the international requirements for a national park (IUCN), it was to be transformed into a $\mathrm{BR}$ in a large-scale participation process. The process is led by the administration of the existing NP. More than 300 events have taken place in the region in recent years. The region includes four municipalities. Its economy is characterized by tourism, agriculture and forestry (Jungmeier et al. 2008a, 2008b; Pichler-Koban \& Jungmeier 2006; Golob 2005).

\section{Selected results}

Nockberge NP - a park influenced by transition aspects

The memory mapping (see Figure 3), participatory observation during the trainshop, ten qualitative interviews and a regional feed-back workshop all show that the stakeholders involved perceived the initiative to establish a national park in the 1980s as a major negative impact. The continuous activities of the NP management team turned this perception into a more positive one. Early in the new millennium, the initiative to change the NP into a BR was again perceived very negatively. This process was initiated by the administration of the NP, supported by working groups from different regional sectors. The process was to be handled with a strong orientation on participation. At the political level, the voluntary participation of the main target group, the landowners / forestry-enterprises was declared a basic principle. While the government strongly supported the concept of a BR, promoters within the region were missing or at least not present in public debate. It was clear to decision-makers that the transformation would more likely adapt the legal framework to existing land uses than change the land uses in line with new regulations. That is why the transformation process was meant to be quite fast. No major obstacles were expected. However, the debate has struggled on and no final solution has been found. The need for rezoning the area caused extensive discussion with the authorities, decision-making bodies and individuals. Currently, development has restarted, embedded in a very positive atmosphere, and will probably lead to the establishment of a BR in 2012.

In the course of this evaluation process, the following conclusions were drawn by the research team:

Governance / participation and the issue of trust and emotions: planners and managers have an important but limited influence on the harmonious establishment and management of a BR. Population and land owners have long memories, technical planning or discussions do not reach the emotions and trust is the most important currency in these processes.

Participation or having a say: in day-to-day life, there are limited possibilities of having a say on public issues. The participative development of a BR seems to act as an outlet for general democratic deficits, bringing past failures and topics to resurface. BRs can
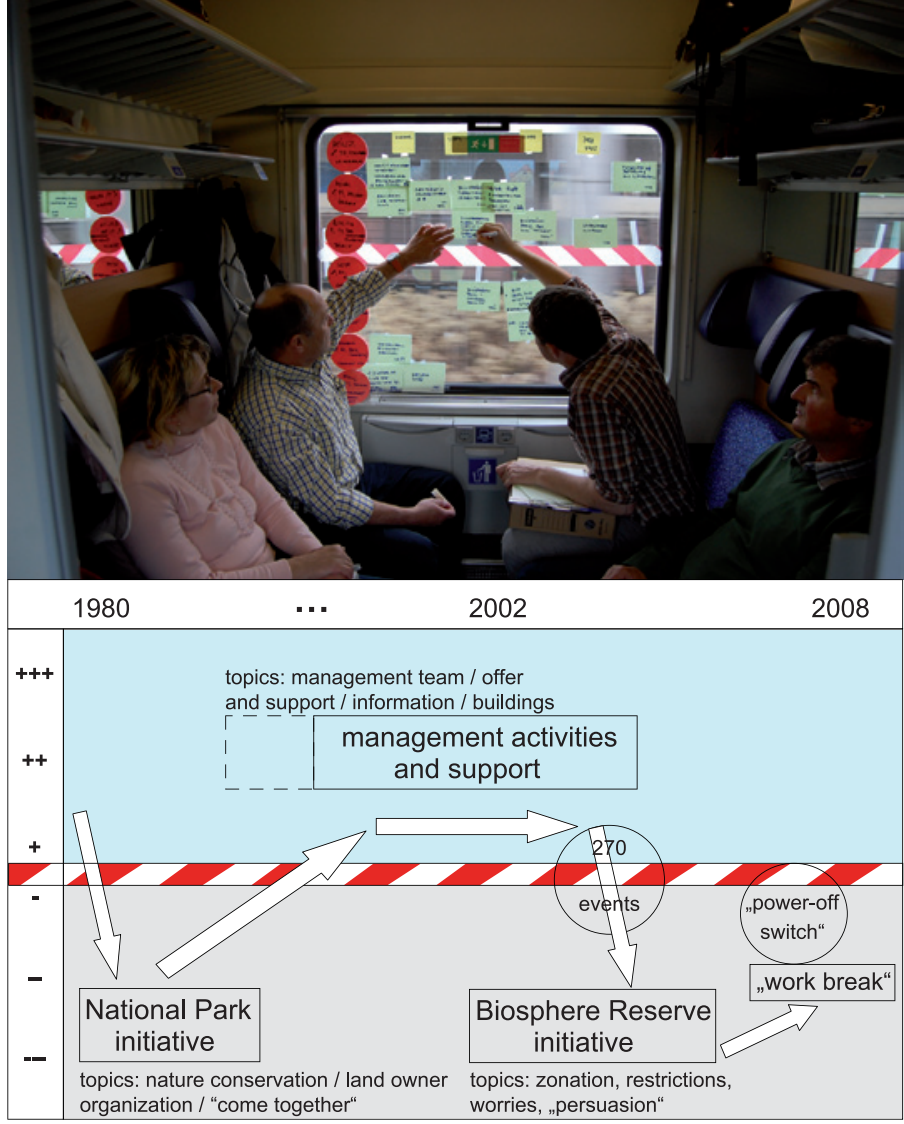

Figure 3-Memory mapping and visual representation of the results for Nockberge NP.

In a special workshop design in a semi-public space (train-shop), we collected individuals' perception of incidences in the planning or management of the park. The diagram presents the collected, analysed and clustered information as ups and downs of perceptions (arrows) across time and main incidents (Authors' design).

be handicapped in their development if historical topics overlap with future topics. However, participation needs to be learned and continuously exercised by the different actors.

Großes Walsertal BR - small, but a beautiful story

Standardized questionnaires, a memory map and a regional feedback workshop demonstrated that this BR development included aspects with a positive influence and logically designed steps within the process. The intention to establish a BR was driven by a regional initiative (bottom-up, see Figure 4) and handled consensually. The BR was a key idea but not a must for the region and at first restricted to a 5 -year trial period. The process included incentives and active, targeted support. The main promoters were from the region but well supported by actors from outside. The process, including the trial period, was not too fast and not too slow. A public appeal was made with the aim of involving the wider public in an open process. Various measures (e.g. logo competition in schools) involved different groups actively. It is very striking that land owners and environmental organizations were accord- 


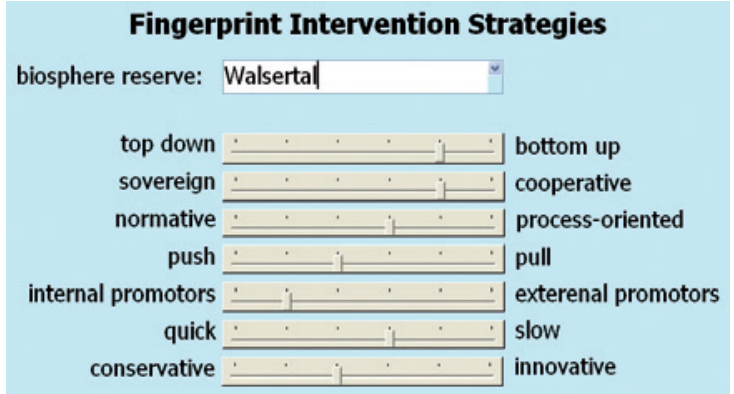

Figure 4 - Fingerprint of the intervention strategies in Großes Walsertal BR.

By presenting different forms of implementation/intervention strategies (identified in the individual processes) as antagonistic elements, the so-called fingerprint can provide a good overview as a basis for further interpretations (Authors' design).

ed equal weight in the process. The reason was that a protected area already existed within the planned area. The new concept would not change the main regional activities much but rather support and steer them into a (more) sustainable direction. Overall, the applied strategy mix seems to have been successful (Coy \& Weixlbaumer 2006).

From the discussion and evaluation of the Walsertal case study, the research team derived the following general conclusions:

Participation and the issue of disillusion: participative planning encourages high expectations (euphoria). The scope of the BR management (long-term perspectives, intangible benefits, low legal competences etc.) tends to disillusion the actors at a certain stage (standard atmosphere). Initially strong networks tend to decline after some years.

Participation and the issue of the active pool: a major challenge for smaller communities, as in Großes Walsertal BR, is the ongoing motivation of people to participate actively. During the initial phase of participation processes, people can be activated easily through personal appeals. Over the years, however, people are tiring and in a small community it is hard to find other people to get involved.

Intervention and the issue of an open process: a key success factor of a regional process is openness. Participation processes with a fixed result (BR, NP, etc.) automatically produce resistance. The decision to go for a BR should be a result of, rather than a precondition for, the debate in the region.

Intervention and the issue of a mixed perception: within regional activities as a whole, people find it hard to distinguish between BR-related activities and those not initiated by the BR management. This circumstance can have positive as well as negative effects on the BR, depending on the allocation of specific activities to the BR management.

\section{Wienerwald BR- management under spe- cial conditions}

Memory mapping, a Delphi survey and a regional feedback workshop threw up some very interesting aspects of the process of this BR development. The driving forces behind the establishment of Wienerwald BR were two departments of the federal states of Vienna and Lower Austria. The process had some participatory / consultancy components. After a feasibility study, the decision was taken to establish a BR. Political support for this idea was very strong. External promoters were the main actors but the relevant local landowners were also involved. Any changes in land use (core zones) were voluntary and based on (attractive) contracts. The process was condensed into a short period of two years. The pragmatic mixture of the strategy components was obviously effective for establishing the BR. The approach was successful: the BR is now officially established, internationally recognized and has a working management body.

As Figure 5 shows, land-owners, farming/forestry enterprises and environmental organizations were the main target groups. The top-down approach as well as the very large area led to a very focused and pragmatic participation process. The issue of diversity did not play a dominant role. In the ensuing years, a lot of efforts were made by the management to involve different groups from different bodies in the area. However, the BR management will still have to show that the condensed and focused mode of implementation that left out many aspects and stakeholders will not block future participation processes.

From the evaluation of the Wienerwald case study, the research team derived the following general conclusions:

Governance and the network issue: the appropriate form of governance in managing BRs is a network that takes on the role of mediator between all actors. By assembling expertise and personal resources, regional management authorities are becoming powerful agents of regional development. The influence and success of a BR is largely determined by its regional networking capital (basic set of actors). The ability of the BR to communicate (communication) and to bring different actors together (cooperation) are important components.

Governance, identity and the occupation of social space: very large BRs often have more than one identity. The management is therefore called upon to provide impulses for strengthening a common self-image. The creation of a brand and the occupation of social space by the inhabitants of the BR are crucial for the success of very large areas.

Participation and the issue of learning sites: BRs act as a platform for learning processes and as a framework for the emergence of new activities. By participating in these BR activities the inhabitants develop trust at a regional level (basis of social capital) and 
civil engagement. In a comprehensive dialogue, they will learn about BR targets as well as from each other.

\section{General discussion of results}

The three areas started from quite different positions for establishing a BR: while the implementation of a BR in the Großes Walsertal was seen as an opportunity for the area to benefit from sustainable development, the creation of a BR in the Wienerwald was seen by the provincial governments more as an alternative for an unwanted national park. The Nockberge are an outstanding example of transforming an internationally not recognized national park into a BR - with the NP management involved in the planning process of the BR. Out of these differences evolved only a few common and many different forms of participation, conflicts in planning processes and ways of involving stakeholders.

Comparing the three case studies, what becomes clear is the relevance of clear leadership, a shared vision, motivating ideas for first steps and participatory processes that ensure the involvement of diverse stakeholders. The decisive role of a clear leadership was also pointed out for projects and protected areas in the Alps by Jungmeier et al. (2006).

As outlined by Lahner (2009), governance processes in BRs are highly interdependent with strategies of creating space and the construction of cultural landscapes. From the case studies of this project it becomes clear that a strong sense of regional identity, as apparent in Großes Walsertal BR and Nockberge NP, facilitates joint orientations (e.g. regional identity, social capital, etc.). Although participatory boards have been successfully implemented in Wienerwald $\mathrm{BR}$, a more detailed vision for the future is missing (to date). Negative path dependencies from the top-down process of the early years still influence current and future-oriented processes.

In Großes Walsertal BR, local people were initially easy to motivate to participate as they expected positive changes, there were no real alternatives and dissatisfaction with the original situation was high. With the exception of this BR, the involvement of women and teenagers has been widely neglected in the planning phase, a shortfall which was also observed in German BRs (Meyer \& Klingele 2007; Baranek et al. 2004). In contrast, the Nockberge region had negative memories of protected area issues in the past, which dampened the enthusiasm for establishing a BR from the start of the planning phase. This corresponds to Pfefferkorn et al. (2006), who found that negative experiences in the past often inhibit fruitful discussions in participatory processes. The sheer size of Wienerwald BR makes it difficult to open up opportunities of understanding and engagement for all inhabitants, making broad identification and motivation difficult. The importance of transformation phases is obvious in Nockberge NP. The interruption of an almost

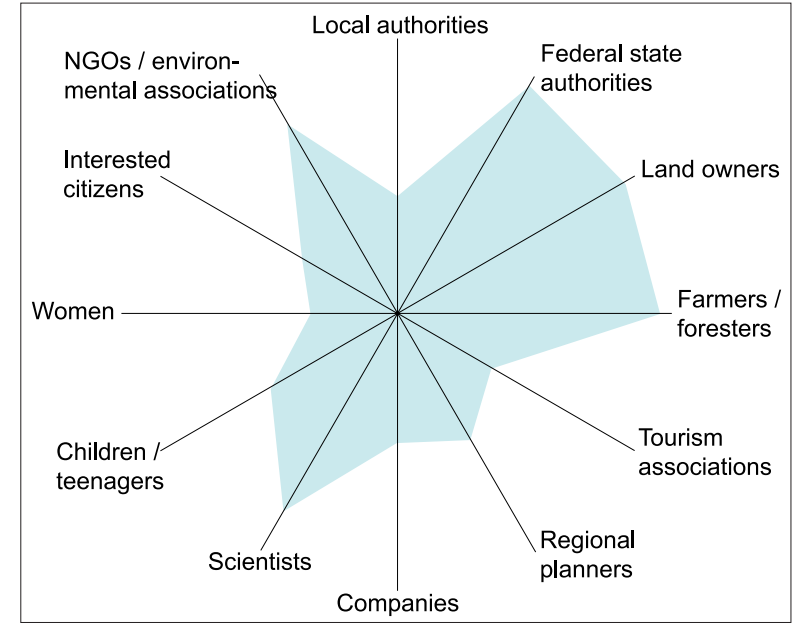

Figure 5 - Fingerprint of the stakeholders involved in Wienerwald BR.

The degree of stakeholder involvement was estimated from the collected information (Authors' design).

completed regional process establishing Nockberge as NP with a new definition as BR clearly disturbed the transformation phases. No time was set aside for grieving and closing the previous plan. Moreover, the new change has been understood in the main as externally driven without clear leadership commitment.

\section{Outlook}

The implementation of a BR is undoubtedly a complex process, in which various issues must be analysed, negotiated and resolved. The project indicates that existing planning methods and approaches - although sometimes successful - often do not match the new demands of integrative BR planning and management as envisaged in the Seville Strategy. The development of BRs requires new qualities, improved concepts and instruments for new ways of planning. This is the only way to make BRs regional models for solving global challenges (e.g. Fischer-Kowalski \& Haberl 2007). Some general considerations and recommendations:

- Sovereign and legal instruments, plus purely civil and participative commitments, are insufficient. The new process architecture must leave the door open for both a result-oriented and a process-oriented approach. It is advisable to determine this at the very beginning of a process, e.g. by means of the fingerprint intervention strategy (see Figure 4). The Seville Strategy envisages BRs as learning sites for new planning concepts made up of well-known and new methodological components.

- Planning a BR essentially means trying to plan the unplannable. Socio-political development and technical planning need to be merged to arrive at coherent new solutions. Intervention research should be part of the game and come in at an early stage.

- New planning implies opening up traditional perceptions of roles and responsibilities: stakeholders become planners, planners become stakeholders. 
Groups of actors become decision-makers, participants become observers, and vice versa. The roles may change frequently within a process and therefore a continuous re-determination of the roles and their understanding is needed. Planners should work out a concrete planning handbook (roadmap) with the decision-making bodies.

- New skills are required of all stakeholders, especially for the decision-makers and planning bodies within the region. For this reason, they should be specially trained and/or experienced. Furthermore, attention must be paid to the composition of the planning team. It should represent the diversity of stakeholders and develop solutions within a transcultural and transdisciplinary discourse and dialogue.

\section{Acknowledgments}

Our special thanks goes to Christian Diry, Irene Drozdowski, Andreas Duller, Heinz Maier, Ruth Moser, Dietmar Rossmann and Josef Türtscher for helpful support and substantial inputs. Many thanks also to Peter Heintel, Martin Coy, Günter Köck and Marina Fischer-Kowalski for keeping a critical scientific eye on the project. Finally we thank our interview partners, workshop participants and stakeholders in the region for their interest, hospitality and frank comments.

\section{References}

Arge Wienerwald 2002. Machbarkeitsstudie Wienerwald - Eignung des Wienerwaldes für einen Nationalpark oder Biosphärenpark. Unpublished manuscript. Vienna.

Baranek, E., B. Günther \& Ch. Kehl 2004. Moderationsverfahren begleitend zur Pflege- und Entwicklungsplanung für das Gewässerrandstreifenprojekt im Biosphärenpark Spreewald. In: Deutsches MABNationalkomitee (Hrsg.), Voller Leben. UNESCOBiosphärenparke - Modellregionen für eine Nachbaltige Entwicklung. Bonn.

Borrini-Feyerabend, G. 2004. Governance of protected areas, participation and equity. In: Secretariat of the Convention on Biological Biodiversity (ed.), Biodiversity issues for consideration in the planning, establishment and management of protected areas sites and networks. Convention on Biological Diversity Technical Series 15. Montreal.

Bridges, W. 2003. Managing Transitions: Making the Most of Change. Cambridge

Coy, M. \& N. Weixlbaumer 2006. Zukünftige Entwicklungsstrategien für den Biosphärenpark Großes Walsertal. Eine regionalwirtschaftliche und perzeptionsgeographische Analyse. Vienna.

Dannemiller Tyson Associates 2000. Whole Scale Change Management. Unleashing the Magic of Organisations. San Francisco.

Erdmann, K.-H., U. Brendle \& A. Meier 2004. Kommunikation und Kooperationen. In: Deut- sches MAB-Nationalkomitee (Hrsg.), Voller Leben. UNESCO-Biosphärenparke - Modellregionen für eine Nachhaltige Entwicklung: 59-65.

Finke, M. 2006. Diversity-Management. Förderung und Nutzung personeller Vielfalt in Unternehmen. München und Mering.

Fischer-Kowalski, M. \& H. Haberl 2007. Socioecological Transitions and Global Change. Trajectories of Social Metabolism and Land Use. Cheltenham, Northampton.

Flick, U., E. von Kardorff \& I. Steinke (eds.) 2009. Qualitative Forschung - Ein Handbuch. Reinbek bei Hamburg.

Getzner, M., M. Jungmeier \& S. Lange 2010. People, Parks and Money. Stakeholders involvement and regional development: a manual for protected areas. In: Getzner, M. \& M. Jungmeier (eds.), Proceedings in the Management of Protected Areas 2.

Getzner, M. \& M. Jungmeier (eds.) 2009. Improving Protected Areas. Proceedings in the Management of Protected Areas 1.

Getzner, M., M. Jungmeier, B. Pfleger \& W. Scherzinger 2008. Evaluierung 5 Jahre Nationalpark Gesäuse. Klagenfurt.

Girtler, R. 1992. Methoden der qualitativen Sozialforschung. Wien, Köln, Weimar.

Golob, B. 2005. Biosphärenpark Nockberge Phase 1 Ergebnisse. Ebene Reichenau.

Graham, J., B. Amos \& T. Plumptree 2003. Governance principles for protected areas in the $21^{\text {st }}$ century. Prepared for the $\mathrm{V}^{\text {th }}$ IUCN World Parks Congress, Durban, South Africa.

Häder, M. 2008. Die Delphi-Methode. In: Bröchler, S. \& R. Schützeichel (eds.), Politikberatung: 33-46. Stuttgart.

Heintel, P. 2003. Interventionsforschung. In: Heintel, P., L. Krainer \& I. Paul-Horn (Hrsg.), Klagenfurter Beiträge zur Interventionsforschung 2: 21-26.

Hussong, H. 2006. Auf dem Weg zur Biosphäre Bliesgau. Der Einfluss regionaler Akteure auf den Prozess der Implementierung eines Biosphärenparks im Bliesgau. Saarbrücker Landeskundliche Arbeiten. Reihe landeskundlicher Online-Publikationen des Instituts für Landeskunde im Saarland e.V. 1.

Inversini, S. 2008. Situationsangepasstes Change Management - Untersuchung zu einem Kontingenzansat:. Saarbrücken.

Jungmeier, M. \& D. Zollner 2004. Biosphere Reserves in Austria - Grundlagenerbebung und Stand der Forschung. Klagenfurt.

Jungmeier, M. \& H. Kirchmeir 2008. WebGIS. Pfichtenheft für den Biosphärenpark. Wienerwald. Klagenfurt.

Jungmeier, M., Y. Kohler, C. Ossola, G. Plassmann, C. Schmidt, P. Zimmer \& D. Zollner 2006. Can large protected areas be instruments of sustainable development and at the same time suitable instruments for protecting natural diversity? Report of Project Question 3: Protected Areas. CIPRA. 
Jungmeier, M., C. Pichler-Koban \& D. Zollner 2008a. Biosphärenparkentwicklung Nockberge - Tätigkeitsbericht. Klagenfurt.

Jungmeier, M., C. Pichler-Koban \& D. Zollner 2008b. Biosphärenparkentwicklung Nockberge - Dokumentationsband. Klagenfurt.

Jungmeier, M., H. Kirchmeir, M. Kühmaier, I. Velik \& J. Wagner 2005. The IPAM-Toolbox: An Expert System for Integrative Planning and Managing of Protected Areas. In: Conference Volume $3^{\text {rd }}$ Symposion of the Hohe Tauern National Park for Research in Protected Areas Areas (September 15-17, 2005, Kaprun Castle): 83-89. Kaprun.

Kastenhofer, K. 2009. Wissenschaftskulturen in den Nichtwissenschaften: Der Umgang mit Nichtwissen und Risiko. Präsentationsunterlagen im Zuge der Fachtagung „Wissenschaftskulturen“ auf der Universität für Klagenfurt, 11.11.2009.

Kirchmeir, H., M. Jungmeier, M. Kühmaier \& C. Pichler-Koban 2005. Detailplanung zum Biosphärenpark Wienerwald. Bereich Wald. Klagenfurt.

Kniberg, H. 2009. Kanban vs Scrum - bow to make the most of both, Version 1.1. (2009-06-29), original Version (2009-04-18). Available at: http://www.crisp. se/henrik.kniberg/Kanban-vs-Scrum.pdf (accessed 1/3/2011)

Köck, G., G. Koch \& C. Diry 2009. The UNESCO Biosphere Reserve ,Biosphärenpark Wienerwald' (Vienna Woods) - a Long History of Conservation. eco.mont 1(1): 51-56.

Krainz, E. \& I. Paul-Horn 2009. Metapher als Intervention. Die bewegende Kraft sprachlicher Bilder: Zeitschrift Gruppendynamik und Organisationsberatung 1: 22-46

Lackner, D. \& G. Loiskandl 2007. Das Zukunftskonzept für den Wienerwald - UNESCO Biosphärenpark. Perspektiven 7: 19-20.

Lahner, M. 2009. Regional Governance in Biosphärenparken. Eine Analyse am Beispiel der Regionen Rbön und Schalsee unter Einbeziehung von Place-Making. Stuttgart.

Meyer, Ch. \& I. Klingele 2007. Biosphärenpark Rhön: Partizipation im Ökosystemaren Ansatz und historischer Rückblick. Beiträge Region und Nachhaltigkeit - zur Forschung und Entwicklung im UNESCO-Biosphärenpark Rbön 4: 140-159.

Paul-Horn, I. 2006. Psychoanalytisch orientierte Organisationsbeobachtung. Erfahrungen mit einer Methode. In: Heintel, P., L. Krainer \& I. Paul-Horn (eds.), Beiträge zur Interdisziplinären Ringvorlesung. Interventionsforschung. Klagenfurter Beiträge zur Interventionsforschung 4: 95-104.

Heckl, F., M. Letigeb-Zach, W. Pfefferkorn \& T. Gottsberger 2006. Vielfalt statt Zwiespalt. Begleitfaden zum Mitgestalten von Lebensräumen - ein Beitrag zur Umsetzung der Biodiversitätskonvention. Wien

Pichler-Koban, C. \& M. Jungmeier 2006. Biosphärenpark Nockberge - Planungsleiffaden. Klagenfurt.

Reutz-Hornsteiner, B. 2001. Der UNESCO Biosphärenpark Großes Walsertal - natürlich men- schlich - vom Leitbild zur konkreten Umsetzung. In: CIPRA Österreich (Hrsg.), Tagungsband CIPRA Österreich Jahresfachtagung 2001 „Wer hat Angst vor Schutzgebieten?": 111-120. Wien.

Reutz-Hornsteiner, B. 2002. Entwicklung von unten - der Weg des Biosphärenparks Großes Walsertal, Österreich. In: Mose, I. \& N. Weixlbaumer (eds.), Naturschutz - Großschutzgebiete und Regionalentwicklung 5: 40-55.

Reutz-Hornsteiner, B. 2003. The Grosses Walsertal Biosphere Reserve in Austria: ,Taking the future in our hands“. In: MAB Programme, UNESCO (ed.), Biosphere Reserves Bulletin of the World Network 12: 32.

Stoll-Kleemann, S. \& M. Welp 2008. Participatory and Integrated Management of Biosphere Reserves. Lessons from Case Studies and a Global Survey. GAIA, Ökologische Perspektiven für Wissenschaft und Gesellschaft S1 (17): 161-168.

Zollner, D., H. Kirchmeir, G. Loiskandl \& M. Jungmeier 2006. Leiffaden für Forschung und Monitoring im Biosphärenpark. Wienerwald. Klagenfurt.

\section{Authors}

Michael Jungmeier

C.E.O. of E.C.O. Institute of Ecology Ltd in Klagenfurt. Co-Director of the MSc programme "Management of Protected Areas", launched by the University of Klagenfurt.

E.C.O.-Institut für Ökologie GmbH, Kinoplatz 6, 9020 Klagenfurt, Austria

jungmeier@e-c-o.at

Ina Paul-Horn

has obtained her degree and venia legendi in philosophy at the Faculty of Cultural Studies at the University of Klagenfurt. Head of the Institute for Intervention Research and Cultural Sustainability (IKN) at the IFF Faculty University of Klagenfurt.

Universität Klagenfurt, Institut für Interventionsforschung und Kulturelle Nachhaltigkeit IFF-IKN, Sterneckstraße15, 9020 Klagenfurt, Austria

Ina.Paul-Horn@uni-klu.ac.at

\section{Daniel Zollner}

is a landscape planner. International project manager at E.C.O Institute of Ecology Ltd in Klagenfurt since 2001. Main focus on planning and managing protected areas, participative processes and on applied research and education.

E.C.O.-Institut für Ökologie GmbH, Kinoplatz 6, 9020 Klagenfurt, Austria

zollner@e-c-o.at

\section{Sigrun Lange}

holds a diploma degree in biology with a focus on tropical high mountain ecosystems (University of Bayreuth, Germany), and an MSc degree in Protected Areas Management (University of Klagenfurt, Austria). 
For nearly 20 years, she has worked in biodiversity conservation and public relations, with field experiences in Papua New Guinea, Ecuador, Peru, Kenya, and Ethiopia. For the last seven years, she has concentrated on protected areas management, especially biosphere reserves and cross-border cooperation in protected areas management. In 2008 she became CEO of E.C.O. Germany (Munich), a firm specializing in communication, management and planning processes in protected areas.

Dipl.-Biol. Sigrun Lange, MSc MPA, E.C.O. Germany GmbH, Eggernstr. 6, 81667 Munich, Germany.

Lange@e-c-o-deutschland.de

\section{Falk Borsdorf}

holds an MA in Political Science and is a freelance academic writer. Currently writing his $\mathrm{PhD}$ thesis on the influence of BRs on local politics. His research themes include environmental, development and Canadian Studies, as well as minority rights.

Höttinger Au 40 b, 6020 Innsbruck, Austria

falk.borsdorf@uibk.ac.at

Karin Grasenick

is founder and CEO of convelop, cooperative knowledge design. Trainer and consultant for diversity management (Technical University of Graz), change management and conflict partnership catalyst.

Bürgergasse 8-10/I, 8010 Graz, Austria

karin.grasenick@convelop.at

Birgit Reutz-Hornsteiner

is a geographer. Former manager of Großes Walsertal BR, since $2007 \mathrm{PhD}$ on benefits of protected areas and independent projects for ecoResponse. Main focus on applied research, participative planning and management, valorization of and education in PAs.

Verein ecoResponse - Institut für Umweltbildung und nachhaltige Entwicklung ZVR 126782869

Fohnstraße 7, 6822 Satteins, Austria

b.reutz-hornsteiner@ecoresponse.org 